\title{
My brilliant apprenticeship
}

lan Britain

ANUHJ Editor, 1968-69

Bland, clinical spaces, like science labs, can be a hothouse of rich intellectual activity, and the same is true in the humanities: you don't need dreaming spires. It was in one of the seminar rooms of the HaydonAllen Building, where no ornament could distract you but the heavy glass ashtrays on the pinewood tables, that I had my baptism into the world of the ANU Historical Journal (ANUHJ). The year was 1967, the Journal was in its fourth year of existence, and a meeting of its 'Editorial Committee' was advertised as taking place in that scrupulously unadorned room. Part of the agenda for the meeting was to recruit new members for the committee. I was a nervy, nerdy first-year history honours student, thirsting for companionship outside of regular classes. (I had come up from Melbourne on a scholarship, and had no long-term friends in Canberra.) Joining the team of the Journal might not have offered the challenges to me of, say, the rowing club, but it provided a kind of professional apprenticeship along with easy conviviality, and so I decided to take the plunge.

My only previous experience had been editing a magazine at school, which mainly meant writing the editorial and selecting the essays, stories and poems to be published. The crucial 'technicalities' of copy editing, proofreading and layout had been left to the master-in-charge. As a committee member of the $A N U H J$, I was initiated into the mysteries of these processes under the charismatic guidance of the managing editor for that year, Jeremy Madin, from whom I also learned how to liaise with the printers (then in faraway Geelong) and to go about seeking advertising from other publications or local publishers and bookstores. I was privileged as well to have a coursework essay of mine published in the Journal's pages, by which alchemical means it was suddenly transformed into an 'article'- the first in my academic career. It was on the fairly obscure topic of two early Christian heresies, the Novationists and the Donatists, and it grew out of the marvellous honours seminar on medieval church history 
conducted by the young John Molony. That was the remarkable thing about honours courses: the degree of specialisation and adventurousness they encouraged at such an early stage in one's intellectual formation.

Another article of mine, on the slightly less obscure topic of 'Victoria, the Chinese and the Federal Idea, 1887-1888', was to appear in 1969; it grew out of the forensically intense course that Barbara Penny devised for the honours stream in Australian history. In 1968, I had graduated to being coeditor of the Journal (with Jeremy) and the year after I was repeating the role with Iain McCalman-who has since gone on to a brilliant academic career and become a lifelong friend of mine. I am afraid we did not always forbear from publishing our own stuff in the Journal but, true to our professional aspirations, it had to be vetted by others on the committee or an independent referee. And the committee for 1969 was studded with future stars in academic and non-academic fields, notably Rosemary Auchmuty, who has become a leading law professor and pioneer of feminist legal studies in the UK, and Michael Thawley, who was our ambassador in Washington between 2000 and 2005, and later head of the Department of the Prime Minister and Cabinet under Tony Abbott.

Little did I appreciate it at the time, but five to 10 years down the track, when first studying and then teaching at a 'dreaming spires' university in England, it began to occur to me what an extraordinary document the $A N U H J$ was, and what an extraordinary culture it reflected. The undergraduates I taught at my English university were the pick of the crop, and some of them would go on to brilliant academic careers themselves, yet their preliminary training had nothing of the professional rigour, the immersion in original research and its protocols, that were standard characteristics of the Australian history honours degree. They could coast along — and even come out with a first-class degree-without ever having glanced at a primary source or known how to fashion a footnote. The weekly essays they produced for their tutors were often on magisterially broad topics (Irish Home Rule, the Bolshevik Revolution, the evolution of the Welfare State) and gave them an excellent grounding in stylish, compact reporting-all you needed to make an effective civil servant or journalist. But precious few of these exercises would have had any chance of qualifying as a scholarly article.

Sometimes we history honours students in Australia might be at risk of turning into footnote fetishists, but-especially in a department presided over by Manning Clark — there was no danger of our surrendering to jargon and ignoring the role of our discipline as a branch of literature. (Compare 
with what some so-called literature departments were inculcating in budding 'cultural theorists' just a few years later.) On looking back at my own contributions to the Journal, I think I erred on the side of fetishism, but my favourite articles from the 1960s phase-Iain McCalman on Catholic emancipation, Robert Moss on the Indian Mutiny and Mark Downing on the appeasers in Britain in the 1930s_-managed to combine wide-ranging scholarship with a high sense of style. I would have to admit that my top favourite, Bill Mandle's trenchant and sparkling take on WH Auden and the 'Failure of the Left', had no footnotes at all and was by a former Oxford undergraduate and currently one of our lecturers. It was our practice to feature at least one article a year by an 'established academic'-and we indulged Bill's 'look, no hands' approach.

Much further down the track, I had occasion to be grateful in a very practical sense for the training I had received with the $A N U H J$. It was the end of 2001 and I was appointed editor of Australia's longest-running independent literary magazine, Meanjin. It was a daunting responsibility, and the position had been keenly contested. I had to prove myself very quickly, as the appointments committee had taken a punt on someone with a solid academic background but very little editorial experience. The little that I had acquired, however, as a result of that stint in Canberra decades before, turned out to be more than enough to equip me instantly for the challenges involved, and I ended up staying in the position for an exhilarating six years.

At a time now when print journals and specialist honours courses at university seem to be threatened by the same fate as ashtrays in our civilisation, we have great reason to be heartened by the revival of the $A N U H J$. Long may it prosper in this new incarnation, and be as fertile for its team of readers, writers and editors as the original has proven to be.

Ian Britain completed his honours degree in history at The Australian National University in 1971 and was coeditor of the ANUHJ in 1968 and 1969. He studied for his doctorate at Corpus Christi College, Oxford, in the mid to late 1970s, and was subsequently a lecturer in history and politics there. He then lectured in history at the University of Melbourne for several years, and was an Australian Research Council Senior Research Fellow at Monash University before taking up the editorship of Meanjin. He is the author of (among other books) Once An Australian: Journeys with Barry Humphries, Clive James, Germaine Greer and Robert Hughes, and he is currently completing a biography of the Australian artist Donald Friend. 
This text is taken from ANU Historical Journal II: Number 1, published 2019 by ANU Press, The Australian National University, Canberra, Australia.

doi.org/10.22459/ANUHJII.2019.04 